\title{
Research on the Cultivation of Entrepreneurial Talents of Application-oriented Undergraduates Majoring in Financial Management
}

\author{
Jun Feng \\ Wuhan Business University, Wuhan, 430050, China \\ E-mail: 643962705@qq.com
}

Keywords: Entrepreneurial Talents; Application-oriented; Financial Management

\begin{abstract}
The economic globalization has led to the development of capital market, the adjustment of economic structure, and other changes in business environment, which requires the improvement of corporate Financial Management, and thus, more demanding requirements are proposed on the knowledge structure and capabilities of financial management professionals. The training mode of talents of Financial Management major in colleges is facing new challenges. In the first part, the paper explores the talent cultivation for financial management majors in China. In the second part, based on the conditions of colleges, the paper discusses the current status of training model for financial management professionals of universities in China. Finally, some suggestions are proposed for the training model of entrepreneurial talents of application-oriented undergraduates of financial management major to meet the needs of modern market economy.
\end{abstract}

\section{Introduction}

It has been nearly 10 years since China's education department separated the Financial Management major from Accounting and made them develop in parallel with each other. For a long time, due to the lack of a clear division between the major of Accounting and Financial Management, universities in China have accumulated less experience in talent cultivation of Financial Management major. [1] Some colleges have studied the training model of Financial Management majors in the past 10 years. However, generally speaking, some major controversies about the basic issues of professional orientation and training objectives still exist and no universally agreed opinion has been formed. Therefore, the construction of Financial Management major has always been a process of exploration and adjustment, exercised in a cautious and gradual way, just like crossing the river by feeling the stones. [2] It is in the process of cultivating practice to explore and adjust. The cultivation of Financial Management professionals has become a universal concern for universities that currently commence to set up this major. Combined with the experience of development of Financial Management major in Wuhan Business University over the years, this study puts forward some suggestions for optimization of the training program for Financial Management professionals.

\section{Domestic Current Status of Talent Cultivation in Financial Management Major in Colleges}

\subsection{Indefinite Training Objectives}

The indefinite training objectives are caused by three main reasons. Firstly, Accounting, Finance, and Financial Management are very close to each other in terms of curriculum and range of study. Secondly, compared with these professions, the disciplinary characteristics of Financial Management are not obvious in training objectives. [3] Thirdly, at present, the training of Financial Management major in China's colleges only focuses on cultivating basic knowledge and basic skills, while ignoring the teaching of relevant knowledge and the cultivation of abilities.

\subsection{Unreasonable Curriculum System and Overlapped Contents of Professional Courses}

The knowledge of Accounting and Finance is an integral part of the knowledge structure of 
Financial Management, which contributed to that when designing the curriculum system of Financial Management, most colleges tend to either lay particular stress on Accounting or Finance, without an independent, scientific, systematic curriculum system on Financial Management.

\subsection{Insufficient Teaching Staff and Monotonous Teaching Methods}

Since the Financial Management theory was introduced into China for a short period of time, there are very few teachers specializing in Financial Management in universities in China. Besides, the teaching methods and methods of some teachers need to be renewed.

\section{Countermeasures for the Cultivation of Entrepreneurial Talents of Application-oriented Undergraduates Majoring in Financial Management}

\subsection{Optimizing Talent Training Objectives of Financial Management}

Application-oriented universities should develop a distinctive Financial Management professional training model which is suitable for their own development, based on the training objectives of Financial Management set by the Ministry of Education and their own characteristics. For example, Wuhan Business University, a college situated in Wuhan, Huibei province, takes local economic and social development as the direction to cultivate application-oriented and interdisciplinary high-quality talents. [4] By means of combining the training objectives with the market demand for Financial Management professionals, it establishes the training objectives of the Financial Management major, that is, cultivating application-oriented high-quality talents who are equipped with unlimited potential and professional skills of Financial Management such as financial decision-making, financial control, financial analysis, financial Accounting, and capital management to fulfill the needs of local economic development in Hubei Province. The professional direction is specifically divided into four areas: investment and wealth management, tax planning, asset assessment, and credit management. As shown below:

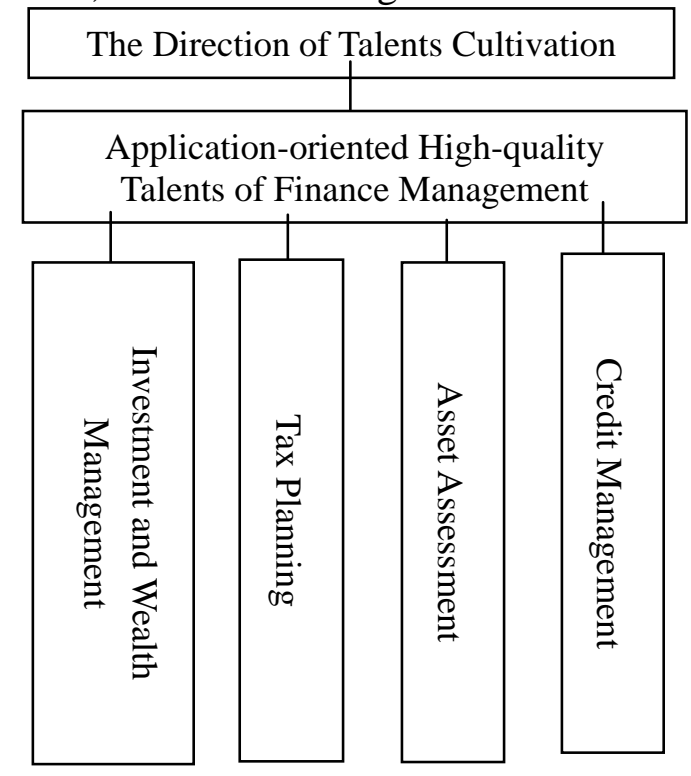

Figure 1 The Direction of Talents Cultivation of Financial Management Major in Wuhan Business University

\subsection{Optimizing the Curriculum Structure System of Financial Management Major}

The orientations of talent cultivation in the three majors of Financial Management, Accounting, and Finance are different. The Financial Management major focuses on cultivating talents who are capable of financial forecast, control, analysis, and decision-making, while the Accounting major focuses on those with ability of accounting and supervision, and Finance on those with ability of financial management needed by financial institutions.

The curriculum structure system should be devised to serve the training objectives of the major. 
The curriculum systems of these three majors should boasts unique disciplinary characteristics. The curriculum of Financial Management major mainly includes Financial Management, Taxation, Advanced Financial Management, International Financial Management, Asset Assessment, etc.; Accounting mainly consists of Basic Accounting, Cost Accounting, Intermediate Financial Accounting, Advanced Financial Accounting, Auditing, etc.; Finance mainly comprises Currency Banking, Financial Theory And Practice, Insurance, International Settlement, Commercial Bank Management and Management, and Securities Investment, etc.. Despite that many courses of Financial Management are overlapped with Accounting and Finance, courses of these three majors all have their own characteristics because some shared lessons are just for students' absorption of professional knowledge.

\subsection{Strengthening Practical Teaching}

As the key to improve students' financial management capacity and practical work ability, practical teaching should be reinforced in application-oriented colleges to strengthen the effect of practical teaching. However, because the high-level position of Financial Management may involve some confidential financial information, it is difficult for interns to participate in the financial management process of the company. Therefore, during the internship, students can only learn the accounting process and have little contact with practical issues of Financial Management. To solve this problem, it is necessary to increase opportunities of inside-school practice, which includes the case teaching method and the ERP sandbox simulation experiment. If well implemented, these two methods will achieve the same effect with off-campus internship.

A variety of case teaching enables students to get access to the actual Financial Management of different enterprises in various industries. In case studies, they can play the role of Financial Management to analyze cases, solve problems by giving their own opinions, and discuss to learn from each other. Through case teaching, students are immersed in corporate Financial Management work, which enhances their ability to make a reasonable decision-making with their own knowledge to in the face of complex financial management problems. Moreover, provided with a large number of cases, students have abundant opportunities to analyze the causes of their mistakes which they can learn from, so that the same mistakes can be avoided in the future work, and learn successful Financial Management experience as well.

Application-oriented colleges should increase funds to the Financial Management major and set up laboratory. [5] The Financial Management major should do experiment in their own laboratory, instead of in the simulated accounting laboratory. ERP Sandbox Simulation Experiment, an experiment which simulates the process of production and operation of enterprises and creates a virtual atmosphere of enterprise by combining the sandbox with ERP software, allows students to conduct a thorough control on the simulative corporate operation process. ERP software integrates all the simulative economic activities of enterprises to realize dynamic management, the integration of corporate finance and economic services, and effective allocation of enterprise funds, personnel, logistics and information. The whole experiment examines the operation of enterprise from the perspective of finance, depicting a more vivid picture for students to understand the process of corporate financial management.

\subsection{Creating a "Dual-qualified” Faculty Team with Reasonable Structure}

"Double-qualified" teacher refers to compound teachers who not only possess certain professional theories and teaching arts, but also have consummate professional skills and rich practical experience to perform dual duties of research and practice. Application-oriented colleges are in urgent need of "dual-qualified" teachers to create a reasonably structured faculty team. This guarantees both the teaching quality of application-oriented colleges and the goal of talent cultivation.

Firstly, it is to strengthen the training of teachers. Application-oriented universities should establish a training system to strengthen the training of teachers, making full use of existing resources for training of "dual-qualified" personnel. Each year some teachers should be selected to participate in the professional skills training and have further studies. Besides, high-quality and 
high-level talents should be hired to give lectures or teach lessons. Through the combination of scientific research, technical services, and production-study methods, teachers' practical skills can also be improved.

Secondly, it is to implement the teacher-to-business practice system. The school encourages teachers to go to companies for research or job training to accumulate skills and practical experience for teaching. Teachers of Financial Management can also work part-time in some Accounting firms, audit firms, financial companies, etc., so that they can enrich their experience, strengthen practical skills, and make themselves "dual-qualified” teachers.

Thirdly, it is to introduce high-level talents with practical skills from enterprises and institutions. Application-oriented colleges should broaden the introduction channels of faculty. Since applied talents of Financial Management should be equipped with practical ability, the universities should increase contact with financial department, Accounting firms and auditing firm of each unit to introduce talents. Besides, those who have rich practical experience can also be hired to serve as part-time teachers, which can optimize the faculty structure and cultivate students' practical ability.

Fourthly, it is to cultivate middle-aged backbone teachers. Experienced middle-aged teachers can be introduced as part-time teachers because they have both teaching experience and good physical and mental state to play the main role in the faculty team.

\section{Conclusions}

The Financial Management major of application-oriented colleges should cultivate high-quality applied talents to fulfill the needs of social production and economic development. According to the goal of talent training, the talent training of the Financial Management major of application-oriented undergraduate colleges should suit the needs of local economic development with reasonable positioning, rational curriculum system design, increasing practical teaching, and rationally structured teaching staff. The graduates should meet the needs of the market in terms of professional quality and knowledge so that these highly qualified Financial Management talents can contribute to local economic and social development.

\section{Acknowledgements}

In this paper, the research was sponsored by Wuhan Business University, and the Project Name is Research on the Cultivation of Entrepreneurial Talents of Application-oriented Undergraduates Majoring in Financial Management (Project No.2017Y002).

\section{References}

[1] Sustainable and Ethical Entrepreneurship, Corporate Finance and Governance, and Institutional Reform in China. Cumming Douglas, Hou Wenxuan, Lee Edward. Journal of Business. 2015

[2] Research on Network Financial Management System Based on E-commerce. Riza Emekter. Social Science Computer Review. 2013

[3] Entrepreneurial ignition of the business cycle: The corporate finance of mal investment. Gabriel A Giménez Roche. The Review of Austrian Economics. 2012

[4] Financial Flexibility, Investment Ability, and Firm Value: Evidence from Firms with Spare Debt Capacity[J] . Maria-Teresa Marchica, Roberto Mura. Financial Management. 2010 (4)

[5] Flexible employment contracts, the psychological contract and employee outcomes: an analysis and review of the evidence[J] . David Guest. International Journal of Management Reviews. 2004 (1) 